\title{
Depoimento
}

\section{Desculpe minha franqueza}

\section{Peter Pál Pelbart, PUC-SP}

Desculpe minha franqueza. Assim começa Jeanne Marie Gagnebin sua arguição, por vezes, antes de espinafrar o candidato em plena solenidade acadêmica. Quando lança essa frasesinha, sabemos que vem bomba, sem pudor quanto à situação, ao interlocutor, à solenidade, à convenção. Sim, todo europeu é capaz de diferenciar as ideias das pessoas que as defendem. As ideias não pertencem às pessoas. Aliás, por vezes, as pessoas são muito menos interessantes do que as ideias que elas enunciam, lembra Jeanne Marie com sua helvética franqueza. Em todo caso, debater as ideias é exercer o direito de expor abertamente aquilo que alguns não ousam dizer, por excesso de cautela, de cordialidade, de medo ou covardia. Mas como ela consegue dizer tal frase sorrindo, enquanto dispara uma crítica devastadora, sem que ninguém saia ofendido - eis um mistério que jamais entendi!

Mas esse mote não funciona apenas como um "abre alas" para a bateria trovejante. É também um modo de se colocar numa situação dada, uma espécie de atitude encarnada, que justamente desfaz o tom neutro ou professoral que seu estatuto ou seus livros ou seu prestígio poderiam ancorar. Desculpe minha franqueza significa que não é a professora eminente que vai se pronunciar, mas uma mulher com sotaque carregado, com seus hábitos estrangeiros, com seu feminismo assumido, com suas reticências em relação àqueles que se levam a sério demais ou têm a presunção de consertar o mundo. Quem fala tampouco tem pudor em usar de maneira sempre leve sua erudição grega, latina, germânica, teológica ou marxista, aliadas à prudência filológica, para desfazer clichês filosóficos que tamponam ou vulgarizam o pensamento. Nessas situações, quem toma a palavra é tudo menos a isenção e a neutralidade ditas "suiças". Donde um pequeno paradoxo, talvez próximo àquele que enfrente o leitor de Nietzsche. Eis uma filósofa que diz "gosto, não gosto, detesto, tenho calafrios, tenho horror, é insuportável, é maravilhoso", não é a voz do saber universal, mas um paladar, um sabor, um filtro, preferências, ojerizas. E isso tem um efeito raro, pois por abstrato que possa parecer, sobretudo aos olhos dos que o idealizam, para Jeanne Marie o saber é desse mundo, o dos embates entre os homens, os sexos, as classes, a mediocridade e a fineza, o medíocre e o sublime, a violência e a tolerância, os vitoriosos e os derrotados, o esquecimento e a memória. A "franqueza" tal como ela a enuncia traz de volta a filosofia a esse mundo, faz da conversa um diálogo deste mundo, des-soleniza o discurso, torna-o moeda corrente, devolve-o ao curso do mundo, ao seu comércio, com tudo o que dele faz parte - a afetividade, a agressividade, a tensão, os risos, o humor, os jogos de palavra. Sabemos a que ponto a autora insiste em suas aulas em entremear com suas falas as mais densas sobre o tempo perdido em Proust trivialidades cotidianas, por exemplo, sobre a madeleine, que não passa de um biscoitinho banal. Isso tem um efeito de desidealização do pensamento ou da literatura, desmontando a intimidação que faz as delícias de certo sadismo professoral - o "pequeno poder" de fazer o outro sentir-se burro, ignorante, incapaz. Enfim, é um gesto de democratização da prática filosófica. Os alunos de Jeanne Marie, mas também seus ouvintes ou leitores, não se sentem diminuídos ou esnobados, muito menos excluídos de uma linguagem

Cadernos Benjaminianos, Número especial, Belo Horizonte, 2013, página 3-7 
deliberadamente hermética que os expulsasse, mesmo quando são exigidos a adentrar a complexidade e os rigores da interpretação filológica.

Às vezes, depois do Desculpe minha franqueza vem o Confesso que.. Por vezes, é aí que tudo se intensifica e cria as mais bizarras situações. Como quando, numa banca sobre Nietzsche, ao lado de um colega e amigo, especialista no assunto, ela ousa dizer: Confesso que não consigo mais ler Nietzsche sem me perguntar se ainda é o caso de escrever sobre ele. A irreverência em relação à história da filosofia e seus cânones consagrados, ou às autoridades no assunto, é mesmo espantosa... O Confesso que apenas reitera que ela fala do fundo de sua ponderação "situada", perspectivada, crítica, portanto "pessoal" e "histórica", sem que justamente isso jamais se torne um ataque "pessoal" ao autor ou ao pesquisador, e muito menos uma posição "subjetiva" ou "subjetivista". O paradoxo parece ser este: é ela falando, uma voz inconfundível, que no entanto nunca se vale da mera autoridade. Não é um Eu neutro e supostamente universal enunciando uma Verdade isenta, mas uma singularidade tomando posição num debate inconcluso, sempre em aberto. Com isso, uma recusa de se levar a sério demais, apesar do currículo invejável ou do status alcançado - daí o contraste com tantos professores, daqui e estrangeiros, que já chegam empedernidos, cuja voz já é radiofonicamente treinada para impor respeito, cuja presunção é já uma arma de intimidação e de ocupação de espaços institucionais ou mesmo midiáticos. Jeanne Marie é aquela que pode começar uma conversa com uma eminência internacional ou numa solenidade pública pelo detalhe mais caseiro, como uma dona de casa o faria, recusando a mistificação. Estou certo que isso tem um efeito para o campo da filosofia, que em nada contradiz suas intervenções as mais agudas no debate nacional, por exemplo, sobre a abertura dos arquivos da ditadura, nomeando a deslealdade dos compromissos assumidos pela reitoria nomeada, ou sobre as questões mais espinhosas do messianismo ou do barroco em Benjamin.

Sei da ojeriza que Jeanne Marie sempre teve da falsa intimidade, da proximidade apenas presumida, da cordata cordialidade que em nossos trópicos amiúde encobre diferenças e intimida a expressão das divergências, quando não a elucidação dos conflitos. Sempre me fascinou um título de um livro por vir, que ela promete publicar em sua velhice: A justa distância. Inúmeras vezes usei a expressão nas situações mais diversas, abusando do seu sentido, seja para justificar meus impulsos de alheamento social ou mesmo conjugal. Certamente na pena de Jeanne Marie essa expressão tem um sentido nada psicológico ou intersubjetivo. E no entanto, ouso sustentar que a justa distância, num sentido afastado daquele que ela deve empregar em seus estudos benjaminianos, é uma espécie de mote de vida no jogo das suas relações com colegas, amigos, com as autoridades, com o saber, com os poderes, com os textos, com o sentido, até mesmo com a filosofia. Isso tem um efeito curioso, pois permite escapar da polaridade da adesão ou inimizade, da fusão ou polarização, abrindo para um saudável pluralismo que ela é uma das poucas a exercer com tamanha liberdade, sem querer "agarrar", como diria Barthes, os que sustentam linhagens distintas.

Não posso deixar de fornecer um exemplo pessoal, embora muito particular. Quando Jeanne Marie aceitou ser minha orientadora de mestrado, em 1984, eu acabava de voltar de meus estudos de filosofia na França, onde segui, em paralelo à graduação feita em Paris IV (Sorbonne), cursos livres com pensadores como Derrida, Deleuze, Lyotard, Foucault, Serres - últimas centelhas do pensamento francês cozido no caldo da conturbada década de Maio de 68, e que em seguida

Cadernos Benjaminianos, Número especial, Belo Horizonte, 2013, página 3-7 
cederia o passo à mais severa reação. Desde o início entendi que esses autores ditos pós-estruturalistas não eram os prediletos de Jeanne Marie, proveniente de outra tradição, mais alemã, mais benjaminiana, mais próxima da teoria crítica, ou da tradição hermenêutica, de autores como Adorno ou Ricoeur. Na minha inocência ou sabedoria, porém, não era isso o que decidiu minha escolha - e sim uma sintonia de outra ordem, relacionada antes a certa abertura de espírito, generosidade com a imaginação alheia, frequentação da literatura, mas também afetividade no trato com os alunos e suas hesitações, com o que, apesar do rigor extremo exercitado a cada dia, vislumbravam-se múltiplas brechas de entrada, de enganche possível. Portanto, não foi a sintonia de raciocínio ou de doutrina, mas a percepção de que meu tema estranho poderia sim ser acolhido por alguém que, embora frequentasse o coração da tradição e adjacências, também se deleitava com seus desvios, bifurcações, inclusive extravios, fossem eles da ordem de uma errância poética ou de um "método" concebido de maneira "menor". Na época eu tinha três "mestres": Foucault, Deleuze, Blanchot. Entendi que Foucault não era seu autor predileto (havia Foucault demais por toda parte, talvez..), que Deleuze não lhe era muito familiar (os alemães em geral não suportam Deleuze, sabemos disso..) e que Blanchot lhe era pouco conhecido. Quanto ao tema da loucura/desrazão, não era sua especialidade, obviamente. Portanto, sua acolhida foi em tudo uma aposta no desconhecido, uma confiança numa aventura insólita, e um gesto de amizade. Talvez Blanchot tenha garantido a ponte, já que era um comentador finíssimo de Kafka, tinha uma intimidade com escritores alemães e franceses, tinha ele mesmo uma escrita e uma profundidade raras. Uma outra ponte provável que estabeleceu entre nós uma cumplicidade: sua tematização do holocausto, do testemunho, da memória. Eu diria, ela sempre falou ao meu coração "judaico", por assim dizer.

Com os anos, apesar das diferenças de peso, fui notando cruzamentos insólitos entre o Benjamin que ela ensinava e o Deleuze que eu cultivava - sobretudo a crítica de certa concepção de história, de tempo, de memória, mas também uma idéia de acontecimento, de suspensão, de cesura, de esquiza, de Jetztzeit, de futuros soterrados, ou o "esburacamento" necessário na continuidade da escrita históricofilosófica (que, claro, cada um dos autores exerce ou tematiza a seu modo), a suspeita reiterada em relação ao culto do eu, a problematização da dívida infinita, da lógica da vingança, e até mesmo um messianismo que em Deleuze, feitos certos saltos, poderia receber nomes distintos. Sempre sonhei em organizar um colóquio a respeito desses dois pensadores que não se conheceram, mas que se cruzam no céu de nossa atualidade.

Se me fosse dado o direito de apontar uma marca que Jeanne Marie introduziu entre nós, eu não hesitaria em dizer, sem pompa alguma, claro, que tem a ver com uma "atitude" em filosofia. Há alguns anos atrás ela se viu no direito de escrever um belo texto que não canso de utilizar com os alunos, sobretudo os principiantes: "O método desviante". Ali expõe como o ensino da filosofia passa também pelos inúmeros desvios, sobre os quais é preciso poder demorar-se e "perder tempo", ter "paciência", preservar uma "lentidão" que é também uma resistência assumida a um despotismo da produtividade e do rendimento mercantil-capitalista, etc. Como ela o diz, na sua conclusão: "Podemos exercer, treinar, mesmo numa sala de aula, sim, pequenas táticas de solapamento, exercícios de invenção séria e alegre, exercícios de paciência, de lentidão, de gratuidade, de atenção, de angústia assumida, de dúvida, enfim, exercícios de solidariedade e de resistência." Nesse contexto, por vezes uma questão aparece como tal para todos, alunos e professores, e isso faz acontecimento.

Cadernos Benjaminianos, Número especial, Belo Horizonte, 2013, página 3-7 
É extremamente precisa, essa maneira de se ver uma aula. Mas há um detalhe minúsculo que diz muito da sua relação com o saber. Nesse mesmo artigo ela menciona um tempo grego, o Aion, diferente de Cronos, e confessa que nunca entendeu direito o que ele significa. Ora, não é frequente que um professor de filosofia já perto da aposentadoria confesse sua ignorância com tamanha desenvoltura. Não saber, não pretender saber tudo, não se permitir falar de tudo só porque se filosofa, poder calar-se, inclusive fazer do silêncio uma virtude.. É uma espécie de abstinência que vai na contramão de uma assertividade prepotente que ainda está presente em tantos lugares.

É verdade que quando jovens, gostamos dos autores que nos possam oferecer também certezas, e assim domar o mundo e seus enigmas. Com o tempo, aumenta nossa suspeita em relação a esses saberes integrais, e vamos acolhendo as brechas, os colapsos, os descarrilhamentos com mais hospitalidade, para não dizer alívio não é preciso carregar tudo, resolver tudo, salvar tudo e todos. E vem talvez esse momento terceiro, em que se pode largar coisas, desfazer-se de fardos, inclusive desistir. Clarice Lispector dizia: "Ah, mas para se chegar à mudez, que grande esforço da voz. [...] E é inútil procurar encurtar caminho e querer começar já sabendo que a voz diz pouco, já começando por ser despessoal. Pois existe a trajetória, e a trajetória não é apenas um modo. A trajetória somos nós mesmos. Em matéria de viver, nunca se pode chegar antes."

E de fato, há um tema que em Jeanne Marie sempre me surpreendeu - sua relação desprendida com a velhice. Em contraste gritante com um culto da juventude, ela sempre me pareceu ter na velhice que vem vindo uma fonte, não um fardo, com as novas liberdades que ela franqueia, seja no plano do "falar francamente", seja no de desfazer-se das solicitações inúteis ou das coerções mundanas, como que por fim liberada para uma leveza outra. Não sei se é uma serenidade aprendida com os "antigos", ou se é uma marca da sua resistência em ser "atual".. Como se do fundo do engajamento com nossa atualidade, ela pudesse enxergar que há sempre algo mais transversal e mais eterno, mais intempestivo ou mais teológico, talvez, que dá a nossas preocupações presentes um toque levemente risível, embora nada desprezível. Lembro como ela finalizou uma arguição num concurso interno meu na PUC, dizendo que era preciso reencontrar o encanto no ato de descascar batatas, não apenas nas experiências-limite de que falava Bataille, Blanchot ou Foucault. Esse retorno às batatas não significava apenas um pragmatismo vital, sempre saudável quando vem na forma de um conselho sábio, mas a intuição de que descascar batatas e ler Heródoto, lutar pela autonomia feminina e meditar Santo Agostinho, falar de Odradek em Kafka e resolver as burocracias da universidade, falar dos anjos às crianças, para ficar numa imagem sintética, não são tarefas pertencentes a mundos diferentes. É possível rir com a filosofia, é possível desfrutar de um acidente na perna para poder reler as confissões de Rousseau, é possível recusar a interferência do Estado nos tratos amorosos, é possível aceitar uma palestra no interior com a condição de ter o almoço livre, sozinha, é possível orgulhar-se da velhice e ganhar com isso uma nova liberdade - enfim, é todo um estilo que aí se desenha. Não sei ao certo como definir essa linha de vida em termos que não maculem o seu repertório, e se tal formulação é mesmo necessária.

No gesto mesmo de coletar esses flashs de vida que compartilhei, na distância e proximidade dos últimos trinta anos, tenho consciência de estar tocando num tema caro à Jeanne Marie, a saber, do estatuto do relato. Seus textos criticaram de maneira suficientemente cáustica a ideia um pouco piedosa de que a rememoração salva, pela

Cadernos Benjaminianos, Número especial, Belo Horizonte, 2013, página 3-7 
palavra, um passado que sem isso correria o risco de perder-se no esquecimento e no silêncio. Na contracorrente dessa tradição, ela evoca uma força esquecediça do próprio relato, que permite uma dispersão liberadora, uma destruição alegre ${ }^{1}$, em que se desfaz o peso da história e da memória, num tempo (outro, mas qual?) onde a morte pudesse ser apagamento feliz, como dizem as últimas e belas palavras de seu livro Histoire et Narration chez Walter Benjamin.

\section{Referências}

J. M. Gagnebin, Histoire et Narration chez Walter Benjamin, Paris : L`Harmattan, 2000.

\section{Notas}

${ }^{1}$ GAGNEBIN. Histoire et Narration chez Walter Benjamin, p. 15. 